\title{
Nuclear hBD-I accumulation in malignant salivary gland tumours
} M Wenghoefer*†1, A Pantelis ${ }^{\dagger 2}$, H Dommisch ${ }^{3}$, W Götz ${ }^{3}$, R Reich ${ }^{1}$, S Bergé ${ }^{4}$, M Martini ${ }^{1}$, JP Allam5, S Jepsen ${ }^{3}$, S Merkelbach-Bruse ${ }^{6}$, HP Fischer ${ }^{6}$, N Novak ${ }^{5}$ and $J$ Winter ${ }^{3}$

\begin{abstract}
Address: ${ }^{1}$ Department of Oral \& Maxillofacial Plastic Surgery, University of Bonn, Sigmund-Freud-Str. 25, 53105 Bonn, Germany, ${ }^{2}$ Department of Otorhinolaryngology/Surgery, University of Bonn, Sigmund-Freud-Str. 25, 53105 Bonn, Germany, ${ }^{3}$ Department of Periodontology, Operative and Preventive Dentistry, University of Bonn, Welschnonnenstr. 17, 53111 Bonn, Germany, ${ }^{4}$ Department of Oral \& Cranio-Maxillofacial Surgery, Radboud University, Nijmegen, Geert Grooteplein-Zuid 14, 6525 GA Nijmegen, The Netherlands, ${ }^{5}$ Department of Dermatology, University of Bonn, Sigmund-Freud-Str. 25, 53105 Bonn, Germany and ' Department of Pathology, University of Bonn, Sigmund-Freud-Str. 25, 53105 Bonn, Germany

Email: M Wenghoefer* - m.wenghoefer@gmx.de; A Pantelis - annwaldeck@gmx.de; H Dommisch - hd2@u.washington.edu; W Götz - wgoetz@uni-bonn.de; R Reich - Rudolf.Reich@uni-bonn.de; S Bergé - S.Berge@mkc.umcn.nl; M Martini - Markus.Martini@unibonn.de; JP Allam - Jean-Pierre.Allam@ukb.uni-bonn.de; S Jepsen - soeren.jepsen@uni-bonn.de; S Merkelbach-

Bruse-Sabine.Merkelbach@uni-bonn.de; HP Fischer - Hans-Peter.Fischer@uni-bonn.de; N Novak - nalija.novak@ukb.uni-bonn.de;

J Winter - jochen.Winter@ukb.uni-bonn.de

* Corresponding author †Equal contributors
\end{abstract}

Published: 7 October 2008

BMC Cancer 2008, 8:290 doi:10.1 186/147|-2407-8-290
Received: 30 October 2007

Accepted: 7 October 2008

This article is available from: http://www.biomedcentral.com//47I-2407/8/290

(C) 2008 Wenghoefer et al; licensee BioMed Central Ltd.

This is an Open Access article distributed under the terms of the Creative Commons Attribution License (http://creativecommons.org/licenses/by/2.0), which permits unrestricted use, distribution, and reproduction in any medium, provided the original work is properly cited.

\begin{abstract}
Background: Whereas the antimicrobial peptides hBD-2 and -3 are related to inflammation, the constitutively expressed hBD-I might function as 8p tumour suppressor gene and thus play a key role in control of transcription and induction of apoptosis in malignant epithelial tumours. Therefore this study was conducted to characterise proteins involved in cell cycle control and host defence in different benign and malignant salivary gland tumours in comparison with healthy salivary gland tissue.
\end{abstract}

Methods: 21 paraffin-embedded tissue samples of benign $(n=7)$, and malignant $(n=7)$ salivary gland tumours as well as healthy $(n=7)$ salivary glands were examined immunohistochemically for the expression of $\mathrm{p} 53, \mathrm{bcl}-2$, and hBD-I, $-2,-3$.

Results: HBD-I was distributed in the cytoplasm of healthy salivary glands and benign salivary gland tumours but seems to migrate into the nucleus of malignant salivary gland tumours. Pleomorphic adenomas showed cytoplasmic as well as weak nuclear hBD-I staining.

Conclusion: HBD-I, 2 and 3 are traceable in healthy salivary gland tissue as well as in benign and malignant salivary gland tumours. As hBD-I is shifted from the cytoplasm to the nucleus in malignant salivary gland tumours, we hypothesize that it might play a role in the oncogenesis of these tumours. In pleomorphic adenomas hBD-I might be connected to their biologic behaviour of recurrence and malignant transformation. 


\section{Background}

The majority of salivary gland tumours are benign. Malignant salivary gland tumours are less frequent but occur in 15 to 32 percent of all patients. The most common point of origin for salivary gland tumours is the parotic gland in up to 80 percent of all cases [1].

Salivary gland tumours show a variety of different morphologic features which complicate the exact histomorphological diagnosis. They might be subdivided into salivary gland tumours with a) myoepithelial components, b) basaloid components, c) epithelial components, d) lymphatic components and e) pleomorphic adenomas [2].

In the investigation of the development of salivary gland tumours as well as in the prediction of their clinical course and possible treatment options, molecular biology has moved into the centre of tumour research. In this context proliferation associated antigens as $\mathrm{Ki}-67$, proto-oncogenes as bcl-2, tumour suppressor genes as $\mathrm{p} 53$ or $\mathrm{p} 21$ and the overexpression of growth-factor binding receptors as HER-2 have been identified as important factors in the malignant progression of these tumours. [3].

Defensines as hBD-1, $-2,-3$ are positively charged peptides with molecular weights ranging from 3.5 to $6.5 \mathrm{kDa}$. Their ability to disintegrate membranes is responsible for their antimicrobial potency against a number of gram-positive and gram-negative bacteria as well as yeasts and certain viruses. Defensins have been detected in different tissues as the epithelia of the oral cavity, the gastrointestinal and respiratory tract, the urinary tract and the vagina as well as in salivary glands [4-7]. HBD-2 and -3 have been detected in the joint cartilage of patients with osteoarthritis thus being involved in the repair processes after cartilage damage in the cause of inflammation [8].

As defensins have been detected in the submandibular glands of patients with oral carcinomas [9] they might also play a role in tumour immunity and disintegration of tumour cells.

Whereas hBD-2 and -3 seem to be related to inflammation, the constitutively expressed hBD-1 might be involved in carcinogenesis. HBD-1 is located in a defensin gene cluster on the short arm of chromosome 8 . There was a cancer specific loss of hBD-1 in $90 \%$ of renal clear cell carcinoma and $82 \%$ of malignant prostate cancer, whereas in benign epithelium the expression of hBD-1 was intact [10]. In oral squamous cell carcinomas of the oral cavity we found a 50 -fold decreased, but not complete loss of human $\beta$-defensin-1 gene expression [11]. Therefore hBD-1 might function as $8 \mathrm{p}$ tumour suppressor gene and thus play a key role in control of transcription and induction of apoptosis in epithelial tumours [12].

This study was conducted to characterise proteins involved in cell cycle control and host defence in different benign and malignant salivary gland tumours in comparison with healthy salivary glands.

\section{Methods}

In this study, 21 tissue samples of 7 patients with confirmed diagnosis of a benign, 7 patients with a malignant salivary gland tumour and 7 healthy salivary glands were investigated: 12 patients were of female and 9 patients were of male gender. The average age at diagnosis was 53.8 years. The healthy salivary gland tissue was collected from patients with head and neck tumours during the surgical procedure of neck dissection; those patients were neither irradiated nor received chemotherapy. Procedures involving the human tissue sampling collection followed a protocol approved by the ethical board of the University of Bonn.

After formalin fixation the tissue samples were embedded in paraffin and cut with a standard microtome (ReichertJung, Heidelberg, Germany) into $2 \mu \mathrm{m}$ sections. Tissues for light microscopic evaluation were stained with Hematoxylin and Eosin (HE) and the diagnosis was confirmed by a pathologist (HPF). Immunohistochemistry was performed for p53, bcl-2, hBD-1, -2, and -3.

\section{Immunohistochemistry}

Formalinfixed, paraffin-embedded tissue sections were used for immunohistochemical staining. After deparaffinization and dehydration, the slides were washed in Trisbuffered saline (TBS, Quartett GmbH, Berlin, Germany) containing $0.1 \%$ BSA. Endogenous peroxidase activity was quenched by incubating the slides in a solution of $700 \mu \mathrm{H} \mathrm{H}_{2} \mathrm{O}_{2}(30 \%)$ in $70 \mathrm{ml}$ methanol. To perform antigen retrieval, the sections were pretreated with pepsin $(0.4 \%)$ for $30 \mathrm{~min}$ at $37^{\circ} \mathrm{C}$. Blocking was done with normal serum. After incubation with primary antibody against p53, bcl-2, hBD-1, -2, and -3 (hBD-1 and p53: Biologo, Kronshagen, Germany; bcl-2: Quartett GmbH, Berlin, Germany; hBD-2: Santa Cruz Biotechnology, Heidelberg, Germany; hBD-3: Gentaur, Aachen, Germany) at room temperature for $60 \mathrm{~min}$.

The slides were then washed in TBS buffer and the HRPconjugated secondary antibody (DAKO, Hamburg, Germany) was added and the slides were incubated at room temperature for $30 \mathrm{~min}$. Afterwards the slides were washed in TBS buffer and incubated with diamino benzidine tetrahydrochloride (DAB) as substrate and counterstained with hematoxylin (Merck Eurolab, Dietikon, Switzerland). Negative controls without primary antibody 
were included in each experiment to verify antibody specificity [13].

The immuno-staining for $\mathrm{p} 53$, bcl-2, and hBD-1, -2, and 3 was analysed using a Zeiss Axio-Imager A.1 microscope (Zeiss, Oberkochen, Germany). Tissue staining was assessed by using + (weak positive), ++ (positive), or (negative).

To quantify the nuclear proportion, 100 cells per specimen were analysed for positive nuclear in comparison with cellular immunostaining in consecutive fields.

\section{Results}

All tissue samples showed specific immunostaining. There was positive immunostaining for the defensins hBD-1, -2 and -3 in all tissue samples: In the benign salivary gland tumours $(\mathrm{n}=7)$ and in the healthy salivary gland tissue ( $\mathrm{n}$ $=7$ ) hBD-1 was located in the cytoplasm. In the three pleomorphic adenomas there was additionally weak nuclear hBD-1 staining.

In the malignant tumours $(\mathrm{n}=7) \mathrm{hBD}-1$ was located in the nucleus. In two of the malignant tumours there was additionally weak cytoplasmic hBD-1 staining. HBD-2 was detectable in the cytoplasm of the ducts in benign ( $\mathrm{n}$ $=7)$ and malignant $(\mathrm{n}=7)$ tumours as well as in the healthy tissue $(n=7)$. HBD-3 was located mostly in the cytoplasm of all tissues, but in one adenoid cystic carcinoma particularly in the nucleus as well.

P53 was positive in five of the malignant and two of the benign salivary gland tumours. The positive p53-immunostaining was very weak and occurred in two oncocytomas.

Bcl-2 was detected only in three of the malignant, but in six of the benign salivary gland tumours. There was no correlation between p53 and bcl-2 immunostaining.

All results are summarised in table 1 and 2 .

Fig. 1 shows the typical hBD-1 staining in an adenoid cystic carcinoma in comparison with healthy salivary gland tissue (fusion figure). Fig. 2 shows hBD-2 and Fig. 3 shows hBD-3 staining in adenoid cystic carcinomas (below) in comparison with healthy salivary gland tissue (above). Fig. 4 shows nuclear and cytoplasmatic hBD-1 staining in a pleomorphic adenoma.

\section{Discussion}

In the present study the protein expression of human beta-defensins hBD-1, $-2,-3$, the tumour suppressor gene p53 and the proto-oncogene bcl-2 was analyzed in healthy salivary gland tissue in comparison with different benign and malignant salivary gland tumours. The most interesting finding indicated, that hBD-1 seems to be shifted from the cytoplasm to the nucleus of the tumour cells in malignant salivary gland tumours. Different benign and malignant tumours were chosen, to demonstrate that the translocation of hBD-1 was to be independent from the type of tumour.

HBD-1 is known to be constitutively expressed in epithelial tissues [6], whereas hBD-2 and -3 are inducible by inflammatory mediators as IL-1 $\beta$. HBD- 2 and -3 are connected to inflammation underlined by the works of other authors as for example Varoga and Paulsen who investigated both mediators in the cause of chronic inflammation of joint tissues as seen in osteoarthritis or rheumatoid arthritis $[8,14,15]$.

There is evidence of a cancer specific loss of hBD-1 in 90\% of renal clear cell carcinoma and $82 \%$ of malignant prostate cancer [10]. In squamous cell carcinomas of the oral cavity we found a 50-fold decreased gene expression of hBD-1 compared to healthy gingiva. In benign lesions of the oral mucosa as irritation fibromas or leukoplakias the hBD-1 gene expression was also decreased (5-fold in irritation fibroma and 2.5-fold in leukoplakia). These observations underline the hypothesis that hBD-1 might function as tumour suppressor gene and thus play a key role in the malignant progression of epithelial tumours [11]. Nevertheless the hBD-1 protein was detected mostly in the nucleus of the malignant salivary gland tumours. Therefore it is surprising, that the protein accumulates in the nucleus although the gene might be down regulated. Maybe by nuclear accumulation the hBD-1 protein downregulates its own promoter. Promoter autoregulation is a well known effect and has been reported for other proteins before [16].

Loss of p53 tumour suppressor gene function is one of the most common genetic events described in human cancer [17]. Immunohistochemical staining for p53 usually shows mutant-type of p53, because the half-life of wildtype 553 protein is too short to detect. Wild-type p 53 contributes to tumour suppression through at least two mechanisms: In response to DNA damage p53 causes the arrest of cell proliferation and/or the induction of apoptosis [18-20]. It has been suggested that p53 may induce apoptotic cell death by down-regulating bcl-2 and up-regulating bax expression $[21,22]$.

The loss of p53 tumour suppressor function leading to deregulations in the apoptotic pathway might cause resistance of certain tumour cells to chemotherapy and radiotherapy [23]. 
Table I: Location of hBD-I, -2, -3, p53 and bcl-2 in malignant, benign and healthy salivary gland tissues (positive ++, weak positive + , negative -)

\begin{tabular}{|c|c|c|c|c|c|c|}
\hline tumour & behaviour & hBD-I & hBD-2 & hBD-3 & bcl-2 & p53 \\
\hline salivary duct carcinoma & malignant & nucleus (and cytoplasm+) & cytoplasm++ & cytoplasm ++ & negative- & positive+ \\
\hline $\begin{array}{l}\text { mucoepidermoid } \\
\text { carcinoma }\end{array}$ & malignant & $\begin{array}{l}\text { nucleus }++ \\
\text { (and cytoplasm+) }\end{array}$ & cytoplasm++ & cytoplasm++ & positive++ & positive+ \\
\hline $\begin{array}{l}\text { adenoid cystic } \\
\text { carcinoma }\end{array}$ & malignant & nucleus++ & cytoplasm++ & cytoplasm++ and nucleus+ & negative- & positive+ \\
\hline $\begin{array}{l}\text { adenoid cystic } \\
\text { carcinoma }\end{array}$ & malignant & nucleus ++ & cytoplasm++ & cytoplasm++ & negative- & negative \\
\hline $\begin{array}{l}\text { adenoid cystic } \\
\text { carcinoma }\end{array}$ & malignant & nucleus++ & cytoplasm++ & cytoplasm++ & negative- & negative \\
\hline carcinosarcoma & malignant & nucleus++ & cytoplasm++ & cytoplasm++ & positive++ & positive+ \\
\hline adenocarcinoma & malignant & nucleus++ & cytoplasm++ & cytoplasm++ & positive++ & positive+ \\
\hline pleomorphic adenoma & benign & $\begin{array}{l}\text { cytoplasm++ } \\
\text { (and nucleus }+ \text { ) }\end{array}$ & cytoplasm++ & cytoplasm++ & positive++ & negative \\
\hline pleomorphic adenoma & benign & $\begin{array}{l}\text { cytoplasm++ } \\
\text { (and nucleuss) }\end{array}$ & cytoplasm++ & cytoplasm++ & positive++ & negative \\
\hline pleomorphic adenoma & benign & $\begin{array}{l}\text { cytoplasm++ } \\
\text { (and nucleus }+ \text { ) }\end{array}$ & cytoplasm++ & cytoplasm++ & positive++ & negative \\
\hline cystadenolymphoma & benign & cytoplasm++ & cytoplasm & cytoplasm++ & negative- & negative \\
\hline cystadenolymphoma & benign & cytoplasm++ & cytoplasm & cytoplasm++ & positive++ & negative \\
\hline oncocytoma & benign & cytoplasm++ & cytoplasm & cytoplasm++ & positive++ & weak positive+ \\
\hline oncocytoma & benign & cytoplasm++ & cytoplasm++ & cytoplasm++ & positive++ & weak positive+ \\
\hline $\begin{array}{c}\text { healthy salvary gland } \\
\text { tissue I }\end{array}$ & healthy & cytoplasm++ & cytoplasm+ & cytoplasm++ & negative- & negative \\
\hline $\begin{array}{c}\text { healthy salvary gland } \\
\text { tissue } 2\end{array}$ & healthy & cytoplasm++ & cytoplasm++ & cytoplasm++ & negative- & negative \\
\hline $\begin{array}{c}\text { healthy salvary gland } \\
\text { tissue } 3\end{array}$ & healthy & cytoplasm+ & cytoplasm++ & cytoplasm++ & negative- & negative \\
\hline $\begin{array}{c}\text { healthy salvary gland } \\
\text { tissue } 4\end{array}$ & healthy & cytoplasm++ & cytoplasm+ & cytoplasm++ & negative- & negative \\
\hline $\begin{array}{c}\text { healthy salvary gland } \\
\text { tissue } 5\end{array}$ & healthy & cytoplasm++ & cytoplasm+ & cytoplasm++ & negative- & negative \\
\hline $\begin{array}{c}\text { healthy salvary gland } \\
\text { tissue } 6\end{array}$ & healthy & cytoplasm++ & cytoplasm++ & cytoplasm+ & negative- & negative \\
\hline $\begin{array}{c}\text { healthy salvary gland } \\
\text { tissue } 7\end{array}$ & healthy & cytoplasm++ & cytoplasm++ & cytoplasm++ & negative- & negative \\
\hline
\end{tabular}

In this study, an interrelation between hBD-1 and p53 as tumour suppressor or bcl-2 as proto-oncogene, was not evident. This might be, for different entities of salivary gland tumours were investigated to underline the effect of the hBD-1-translocation in malignant tumours versus healthy salivary gland tissue or benign tumours. P53 for instance is known to be undetectable in mucoepidermoid carcinomas [2]. The traceability of the presently known tumour-suppressor- or proto-onco-genes might be related to the tumour entity, whereas nuclear accumulation of the hBD-1 seems to be independent from the tumour entity, but related to malignancy.

Table 2: Cellular Localization of hBD-I, -2 and -3 in malignant salivary gland tumours in comparison with healthy salivary gland tissue

\begin{tabular}{|c|c|c|c|c|c|c|c|}
\hline & hBD-I & & & hBd-2 & & hBD-3 & \\
\hline & Total Number of Cells & Nuclear Staining & $\%$ & Nuclear Staining & $\%$ & Nuclear Staining & $\%$ \\
\hline Healthy & 700 & 22 & 3 & 62 & 9 & 31 & 4 \\
\hline Malignant & 700 & 525 & 75 & 88 & 13 & 302 & 43 \\
\hline
\end{tabular}




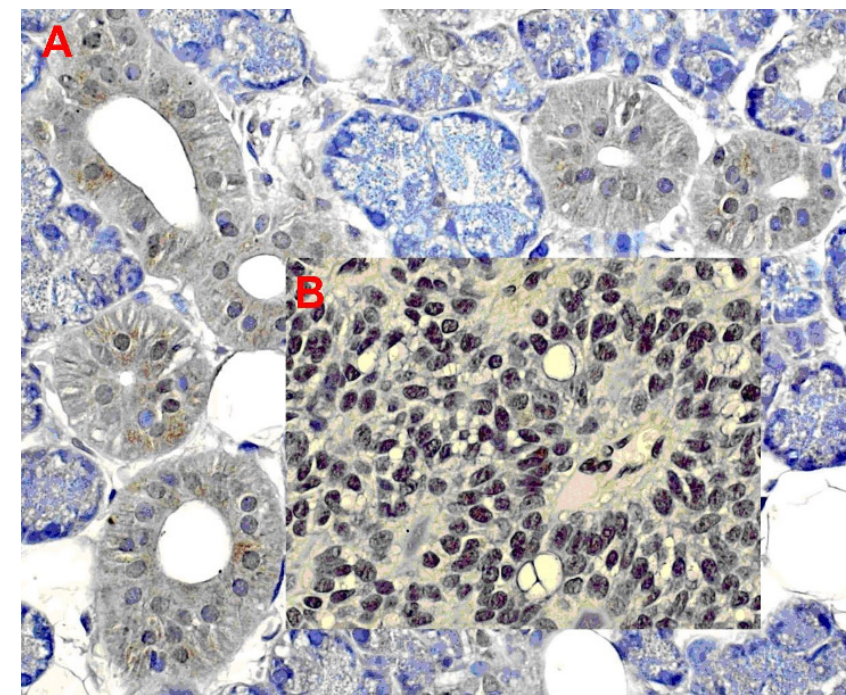

Figure I

hBD I staining in healthy salivary gland tissue $(A)$ and adenoid cystic carcinoma (B).

Sherman and Froy reported that hBD-1 expression is upregulated by c-myc expression, suggesting that c-myc regulates hBD-1 expression via a non-inflammatory pathway [24]. As c-myc is implicated in human cancers, and overexpression of c-myc at the protein and/or mRNA levels has been observed in virtually all types of cancers [25] a hBD-1 involving pathway might play a role in cancerogenesis.

There have been recent reports that the hBD-1 sequence shows homology with known cationic nuclear localized signal sequences in human keratinocytes. Furthermore nuclear localization of hBD-1 in human keratinocytes was described, which suggests a role for this peptide in gene expression [26]. The reason and biological impact of its nuclear translocation in malignant salivary gland tumours is not clear. Further studies should investigate whether hBD-1 protein accumulation is related to a down-regulation of hBD-1 gene expression as it was described in renal clear cell carcinoma or malignant prostate cancer [10]. We have the hypothesis that hBD-1 has abilities of a tumour suppressor gene. Nuclear accumulation of hBD-1 protein could be involved in the malignant progression of salivary gland tumours.

Pleomorphic adenomas are benign mixed tumours. They represent the most common neoplasms of the major salivary glands. It is not uncommon for pleomorphic adenomas to recur, and, though benign a subset will undergo malignant transformation [27]. As there was cytoplasmic as well as weak nuclear hBD-1 staining in the investigated pleomorphic adenomas in this study, this observation

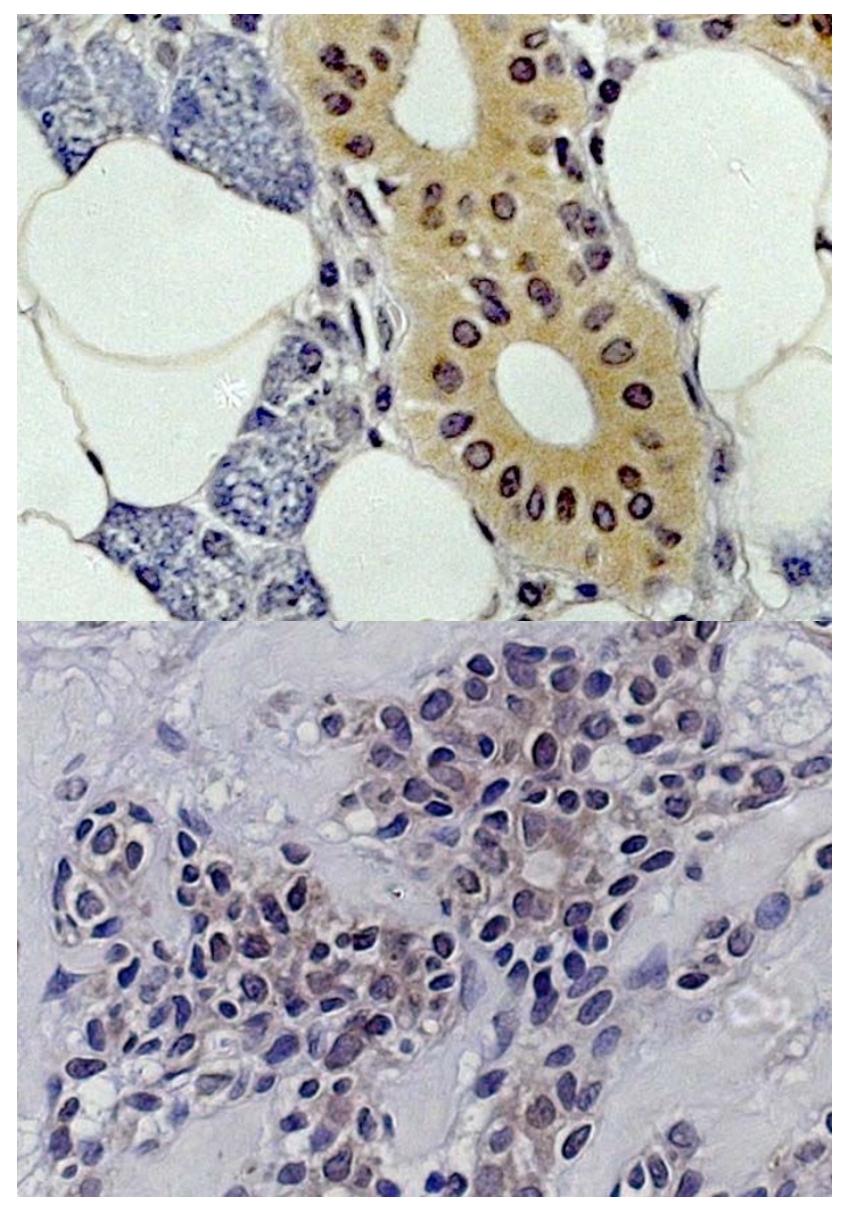

Figure 2

hBD-2 staining in healthy salivary gland tissue (above) and adenoid cystic carcinoma (below).

might underline the role of nuclear hBD-1 translocation in the ability of these tumours to recur or undergo a malignant transformation and should be observed in a greater subset of pleomorphic adenomas.

\section{Conclusion}

1. HBD-1, -2 and -3 is traceable in benign as well as malignant tumours of the salivary glands.

2. We hypothesize that the nuclear shift of hBD-1 might be associated with malignancy in these tumours.

3. Pleomorphic adenomas show nuclear as well as cytoplasmatic hBD-1 staining which might be connected to their biologic behaviour of recurrence and malignant transformation.

\section{Competing interests}

The authors declare that they have no competing interests. 


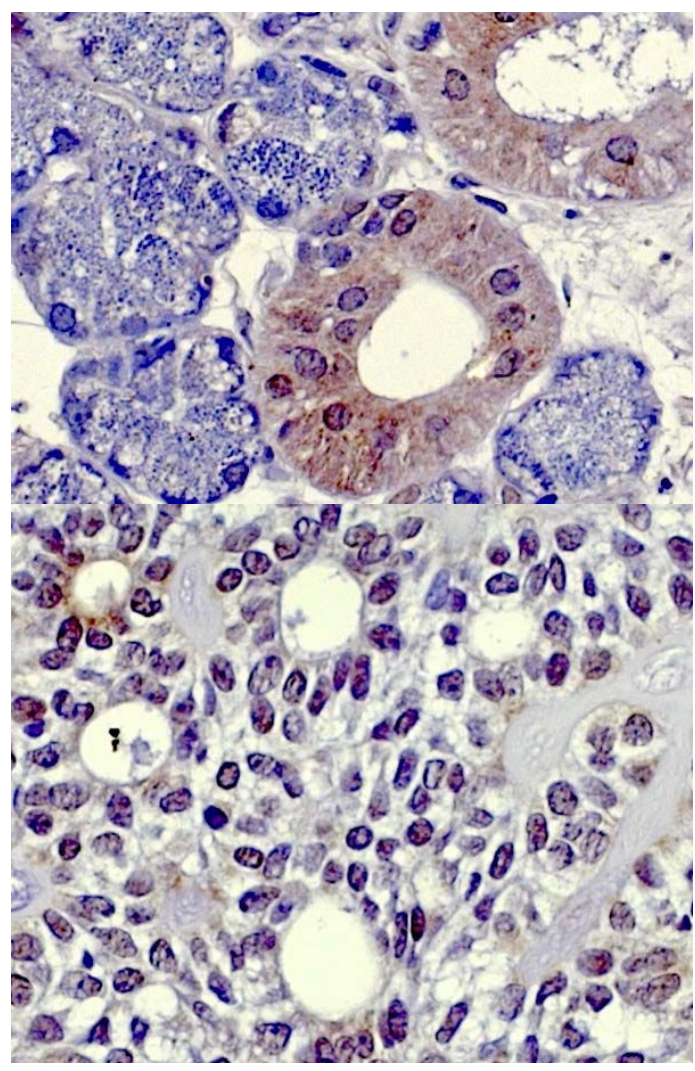

Figure 3

hBD-3 staining in healthy salivary gland tissue (above) and adenoid cystic carcinoma (below).

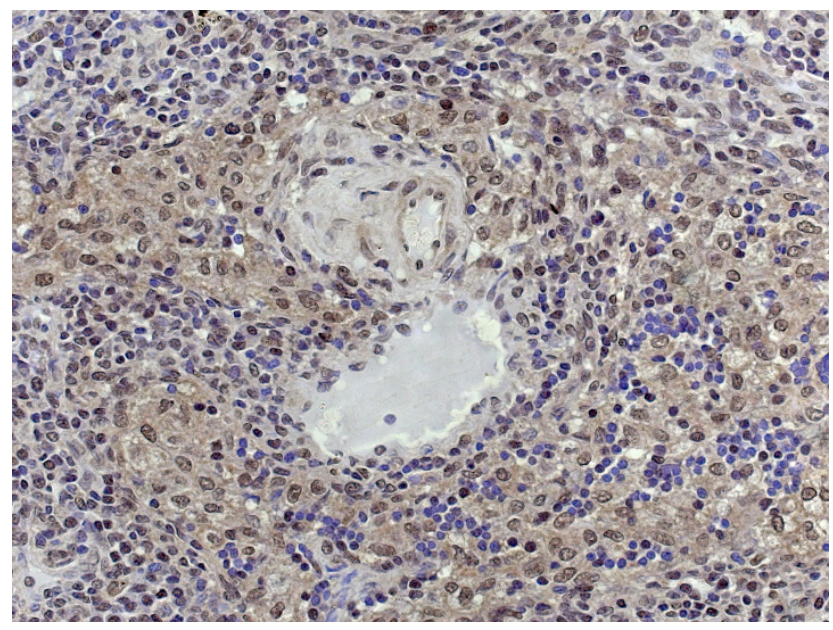

Figure 4

Nuclear and cytoplasmatic hBD-I staining in a pleomorphic adenoma.

\section{Authors' contributions}

HPF confirmed the diagnosis of all tumours. SM-B carried out the immunohistochemistry. JW, AP and MW conceived of the study, and participated in its design and coordination. HD, WG and SJ participated in the design of the study. JPA and NN drafted the manuscript. RR, SB and MM performed the operations and coordinated the tissue sampling and preparation. All authors read and approved the final manuscript.

\section{Acknowledgements}

This study was supported by the BONFOR research foundation of the Medical Faculty of the University of Bonn.

The authors thank M. Tonndorf and T. Nadjafi for their technical assistance during the experiments.

\section{References}

I. de Vicente-Rodriguez JC, Fresno-Forcelledo MF, Gonzalez-Garcia M, Aguilar-Andrea C: Sebaceous adenoma of the parotid gland. Med Oral Patol Oral Cir Bucal I I(5):E446-8. 2006 Aug I

2. Röser K, Jakel KT, Herbst H, Loning T: Immunohistochemical characterization of salivary gland tumors with tissue microarrays. Pathologe 2005, 26(5):345-52.

3. Jaehne M, Roeser K, Jaekel T, Schepers JD, Albert N, Loning T: Clinical and immunohistologic typing of salivary duct carcinoma: a report of 50 cases. Cancer 103(I 2):2526-33. 2005 Jun 15

4. Dommisch H, Acil Y, Dunsche A, Winter J, Jepsen S: Differential gene expression of human beta-defensins (hBD-I, -2, -3) in inflammatory gingival diseases. Oral Microbiol Immunol 2005, 20(3): $186-90$.

5. Dunsche A, Acil Y, Dommisch H, Siebert R, Schroder JM, Jepsen S: The novel human beta-defensin-3 is widely expressed in oral tissues. Eur J Oral Sci 2002, I I 0(2): | 2 | -4.

6. Froy O: Regulation of mammalian defensin expression by Toll-like receptor-dependent and independent signalling pathways. Cell Microbiol 2005, 7( I 0): I387-97. Review

7. Furstenberger G, Krieg P, Muller-Decker K, Habenicht AJ: What are cyclooxygenases and lipoxygenases doing in the driver's seat of carcinogenesis? Int J Cancer I I 9(10):2247-54. Review. 2006 Nov 15

8. Varoga D, Paulsen FP, Kohrs S, Grohmann S, Lippross S, Mentlein R, Tillmann BN, Goldring MB, Besch L, Pufe T: Expression and regulation of human beta-defensin-2 in osteoarthritic cartilage. Pathol 2006, 209(2):166-73.

9. Mizukawa N, Sugiyama K, Kamio M, Yamachika E, Ueno T, Fukunaga J, Takagi S, Sugahara T: Immunohistochemical staining of human alpha-defensin-I (HNP-I), in the submandibular glands of patients with oral carcinomas. Anticancer Res 2000, 20(2B): I I 25-7.

10. Donald CD, Sun CQ, Lim SD, Macoska J, Cohen C, Amin MB, Young AN, Ganz TA, Marshall FF, Petros JA: Cancer-specific loss of betadefensin I in renal and prostatic carcinomas. Lab Invest 2003, 83(4):50I-5.

II. Wenghoefer M, Pantelis A, Dommisch H, Reich R, Martini M, Allam JP, Bergé $S$, Jepsen $S$, Winter J: Decreased gene expression of human $\beta$-Defensin- $I$ in the development of squamous cell carcinoma of the oral cavity. Int J Oral Maxillofac Surg in press. 2008 Mar 15

12. Sun $C Q$, Arnold R, Fernandez-Golarz $C$, Parrish $A B$, Almekinder $T$, He J, Ho SM, Svoboda P, Pohl J, Marshall FF, Petros JA: Human \{beta\}-Defensin-I, a Potential Chromosome 8p Tumor Suppressor: Control of Transcription and Induction of Apoptosis in Renal Cell Carcinoma. Cancer Res 66(I7):8542-9. 2006 Sep I

13. Dommisch H, Winter J, Açil Y, Dunsche A, Tiemann M, Jepsen S: Human beta-defensin (hBD-I, -2) expression in dental pulp. Oral Microbiol Immunol 2005, 20(3): I63-6.

14. Varoga D, Pufe T, Mentlein R, Kohrs S, Grohmann S, Tillmann B, Hassenpflug J, Paulsen F: Expression and regulation of antimicrobial peptides in articular joints. Ann Anat 2005, 187(5-6):499-508. 
15. Varoga D, Pufe T, Harder J, Schröder JM, Mentlein R, Meyer-Hoffert U, Goldring MB, Tillmann B, Hassenpflug J, Paulsen F: Human betadefensin 3 mediates tissue remodeling processes in articular cartilage by increasing levels of metalloproteinases and reducing levels of their endogenous inhibitors. Arthritis Rheum 2005, 52(6): 1736-45.

16. De Falco G, Bagella L, Claudio PP, De Luca A, Fu Y, Calabretta B, Sala A, Giordano A: Physical interaction between CDK9 and B-Myb results in suppression of $\mathrm{B}-\mathrm{Myb}$ gene autoregulation. Oncogene 19(3):373-9. 2000 Jan 20

17. Hollstein M, Sidransky D, Vogelstein B, Harris CC: p53 mutations in human cancers. Science 1991, 253:49-53.

18. Hartwell L: Defects in a cell cycle checkpoint may be responsible for the genomic instability of cancer cells. Cell 1992, 7I:543-6.

19. Yonish-Rouach E, Resnitzky D, Lotem J, Sachs L, Kimchi A, Oren M: Wild-type p53 induces apoptosis of myeloid leukaemic cells that is inhibited by interleukin-6. Nature 1991, 352:345-7.

20. Attardi LD, Lowe SW, Brugarolas J, Jacks T: Transcriptional activation by $\mathrm{p} 53$, but not induction of the $\mathrm{p} 2 \mathrm{I}$ gene, is essential for oncogene-mediated apoptosis. EMBO J 1996, 15:3693-70।.

21. Miyashita T, Krajewski S, Krajewska M, Wang HG, Lin HK, Liebermann DA: Tumor suppressor $\mathrm{p53}$ is a regulator of bcl-2 and bax gene expression in vitro and in vivo. Oncogene 1994, 9:1799-805.

22. Selvakumaran M, Lin HK, Miyashita T, Wang HG, Krajewski S, Reed JC: Immediate early up-regulation of bax expression by p53 but not TGFb I: a paradigm for distinct apoptotic pathways. Oncogene 1994, 9:179|-8.

23. Lowe SW, Ruley HE, Jacks T, Housman DE: p53-dependent apoptosis modulates the cytotoxicity of anticancer agents. Cell 1993, 74:957-67.

24. Sherman H, Froy $O$ : Expression of human beta-defensin $I$ is regulated via c-Myc and the biological clock. Mol Immunol 2008.

25. Nesbit CE, Tersak JM, Prochownik EV: MYC oncogenes and human neoplastic disease. Oncogene 1999, I 8:3004-3016.

26. Bick RJ, Poindexter BJ, Buja LM, Lawyer CH, Milner SM, Bhat S: Nuclear Localization of HBD-I in Human Keratinocytes. J Burns Wounds 7:e3. 2007 Aug 24

27. Sheedy SP, Welker KM, DeLone DR, Gilbertson JR: CNS metastases of carcinoma ex pleomorphic adenoma of the parotid gland. AJNR Am J Neuroradiol 2006, 27(7): 1483-5.

\section{Pre-publication history}

The pre-publication history for this paper can be accessed here:

http://www.biomedcentral.com/1471-2407/8/290/pre

pub

Publish with Biomed Central and every scientist can read your work free of charge

"BioMed Central will be the most significant development for disseminating the results of biomedical research in our lifetime. "

Sir Paul Nurse, Cancer Research UK

Your research papers will be:

- available free of charge to the entire biomedical community

- peer reviewed and published immediately upon acceptance

- cited in PubMed and archived on PubMed Central

- yours - you keep the copyright

Submit your manuscript here:

http://www.biomedcentral.com/info/publishing_adv.asp
BioMedcentral 